\title{
OPEN Toxicity of amantadine hydrochloride on cultured bovine cornea endothelial cells
}

\author{
Po-Yen Lee ${ }^{1,2}$, Yu-Hung Lai ${ }^{1,2,3}$, Po-Len Liu ${ }^{4}$, Ching-Chih Liu ${ }^{5}$, Chia-Cheng Su ${ }^{1,6,7}$, \\ Fang-Yen Chiu ${ }^{1}$, Wei-Chung Cheng ${ }^{8}$, Shiuh-Liang Hsu ${ }^{2}$, Kai-Chun Cheng ${ }^{2,3,9}$, Li-Yi Chiu 1,2,10, \\ Tzu-En Kao ${ }^{2}$, Chia-Ching Lin ${ }^{2}$, Yo-Chen Chang ${ }^{1,2,3}$, Shu-Chi Wang ${ }^{11,12 \bowtie}$ \& Chia-Yang Li ${ }^{1,12 \bowtie ~}$
}

Amantadine hydrochloride $(\mathrm{HCl})$ is commonly prescribed for treating influenza $\mathrm{A}$ virus infection and Parkinson's disease. Recently, several studies have indicated that the use of amantadine $\mathrm{HCl}$ is associated with corneal edema; however, the cytotoxic effect of amantadine $\mathrm{HCl}$ has not been investigated. In the present study, the effects of amantadine $\mathrm{HCl}$ on cell growth, proliferation, and apoptosis in bovine cornea endothelial cells, and in vitro endothelial permeability were examined. Results showed that lower doses of amantadine $\mathrm{HCl}$ do not affect cell growth $(\leq 20 \mu \mathrm{M})$, whereas higher doses of amantadine $\mathrm{HCl}$ inhibits cell growth $(\geq 50 \mu \mathrm{M})$, induces apoptosis $(2000 \mu \mathrm{M})$, increases sub-G1 phase growth arrest $(2000 \mu \mathrm{M})$, causes DNA damage $(\geq 1000 \mu \mathrm{M})$, and induces endothelial hyperpermeability $(\geq 1000 \mu \mathrm{M})$ in bovine cornea endothelial cells; additionally, we also found that amantadine $\mathrm{HCl}$ attenuates the proliferation $(\geq 200 \mu \mathrm{M})$ and arrests cell cycle at $\mathrm{G} 1$ phase $(\geq 200 \mu \mathrm{M})$ in bovine cornea endothelial cells. In the present study, we measured the cytotoxic doses of amantadine $\mathrm{HCl}$ on cornea endothelial cells, which might be applied in evaluating the association of corneal edema.

Amantadine hydrochloride $(\mathrm{HCl})$ is a prophylactic agent originally approved in October 1966 by the Food and Drug Administration (FDA) specifically against Asian influenza ${ }^{1}$. Subsequently, Schwab et al. demonstrated that amantadine $\mathrm{HCl}$ was useful for treating Parkinson's disease (PD) as monotherapy ${ }^{2}$ and in combination therapy with L-dopa and anticholinergic drugs ${ }^{3}$. In April 1973, the FDA approved the use of amantadine $\mathrm{HCl}$ for alleviating symptoms of PD, and it has been widely used in the treatment of PD since then ${ }^{4}$. In addition, amantadine $\mathrm{HCl}$ also shows beneficial effects in the treatment of dengue virus infection ${ }^{5}$, inhibition of West Nile Virus multiplication ${ }^{6}$, and in off-label use to treat fatigue in multiple sclerosis ${ }^{7}$.

Amantadine $\mathrm{HCl}$ has been demonstrated to inhibit influenza A virus replication through inhibition of the ion channel function of M2 protein $^{8}$. In vitro doses from 1 to $10 \mu \mathrm{M}$ are enough to achieve $50 \%$ inhibition of most influenza viruses ${ }^{8}$. For the treatment of $\mathrm{PD}$, amantadine $\mathrm{HCl}$ acts as a weak antagonist of the NMDA receptor that increases dopamine release and blocks dopamine reuptake ${ }^{9}$. The recommended dosage of amantadine $\mathrm{HCl}$ in adults is $200 \mathrm{mg}$ daily, and the blood plasma values are in the range of $0.3-0.6 \mu \mathrm{g} / \mathrm{mL}^{10,11}$, equal to $1.59-3.19 \mu \mathrm{M}$. Kornhuber et al. indicated that mean amantadine $\mathrm{HCl}$ concentrations in brain tissue ranged from 48.2 to $386 \mu \mathrm{M}$ when patients received amantadine $\mathrm{HCl}$ for $\geq 10$ days and had a drug-free time of $\leq 3$ days $^{12}$, whereas the amantadine $\mathrm{HCl}$ concentrations in cerebrospinal fluid and serum were in the low micromolar range

\footnotetext{
${ }^{1}$ Graduate Institute of Medicine, College of Medicine, Kaohsiung Medical University, Kaohsiung 80708, Taiwan. ${ }^{2}$ Department of Ophthalmology, Kaohsiung Medical University Hospital, Kaohsiung Medical University, Kaohsiung 80708, Taiwan. ${ }^{3}$ Department of Ophthalmology, School of Medicine, College of Medicine, Kaohsiung Medical University, Kaohsiung 80708, Taiwan. "Department of Respiratory Therapy, College of Medicine, Kaohsiung Medical University, Kaohsiung 80708, Taiwan. ${ }^{5}$ Department of Ophthalmology, Chi Mei Medical Center, Tainan 71004, Taiwan. ${ }^{6}$ Division of Urology, Department of Surgery, Chi-Mei Medical Center, Tainan 71004, Taiwan. ${ }^{7}$ Department of Senior Citizen Service Management, Chia Nan University of Pharmacy and Science, Tainan 71710, Taiwan. ${ }^{8}$ Graduate Institute of Biomedical Sciences, and Research Center for Tumor Medical Science, and Drug Development Center, China Medical University, Taichung 40402, Taiwan. ${ }^{9}$ Department of Ophthalmology, Kaohsiung Municipal Siaogang Hospital, Kaohsiung 81267, Taiwan. ${ }^{10}$ Department of Ophthalmology, Kaohsiung Municipal Ta-Tung Hospital, Kaohsiung 80145, Taiwan. ${ }^{11}$ Department of Medical Laboratory Science and Biotechnology, Kaohsiung Medical University, Kaohsiung 80708, Taiwan. ${ }^{12}$ Center for Cancer Research, Kaohsiung Medical University, Kaohsiung 80708, Taiwan. ${ }^{凶}$ email: shuchiwang@kmu.edu.tw; chiayangli@kmu.edu.tw
} 
$(<17 \mu \mathrm{M})^{12}$. In addition, the serum levels of amantadine $\mathrm{HCl}$ ranged between 2.6 (a patient who received $200 \mathrm{mg}$ just for 1 day) and $16.3 \mu \mathrm{M}$ (a patient who received $600 \mathrm{mg}$ amantadine $\mathrm{HCl}$ for 10 days) ${ }^{12}$. These results indicate that amantadine $\mathrm{HCl}$ concentration is distributed across a wide range in different tissues. Dosage, duration of treatment, and drug-free time are all associated with mean amantadine $\mathrm{HCl}$ concentration. Although the mean amantadine concentration in the cornea has not yet been examined, it has been reported that amantadine has high penetrative activity into the brain after infusion in rats (brain concentration of amantadine was 16 -fold higher than free concentration in serum $)^{13}$.

In recent years, an increasing number of case reports have indicated that the use of amantadine $\mathrm{HCl}$ is associated with corneal edema ${ }^{14-22}$. A nationwide cohort study in Taiwan also demonstrated that amantadine $\mathrm{HCl}$ increases the risk of corneal edema in a dose-dependent manner ${ }^{11}$; however, how this occurs is still unclear. Corneal endothelium controls the water content of the corneal stroma, whereas corneal endothelial decompensation leads to overhydration of the cornea, known as corneal edema ${ }^{23}$. Thus, in the present study, we aimed to examine whether amantadine $\mathrm{HCl}$ affects cell growth, proliferation and apoptosis in bovine cornea endothelial cells.

\section{Results}

Lower doses of amantadine $\mathrm{HCl}(\leq 20 \mu \mathrm{M})$ do not affect cell growth and viability in bovine cornea endothelial cells. To examine the cytotoxicity effect of amantadine $\mathrm{HCl}$ on bovine cornea endothelial cells, BCE C/D-1b cells were treated with various doses of amantadine $\mathrm{HCl}(0-2000 \mu \mathrm{M})$ for 7 days. At $24 \mathrm{~h}$, the changes in cell morphology were monitored by phase-contrast microscopy. As shown in Fig. 1A, amantadine $\mathrm{HCl}$ did not affect the morphology of cell growth at doses $\leq 750 \mu \mathrm{M}$ after $24 \mathrm{~h}$ of treatment; however, some dead cells were found that had become detached and made clusters of a small number of cells floating in the medium when cells were treated with amantadine $\mathrm{HCl} \geq 1000 \mu \mathrm{M}$ (Fig. 1A). For cell viability, MTT assay was employed for detection from days 1 to 7 . Our experimental results indicated that there was no toxicity when cells were incubated with amantadine $\mathrm{HCl}$ at doses $\leq 20 \mu \mathrm{M}$ for 7 days (Fig. 1B). After $24 \mathrm{~h}$ of treatment, we found that cell viability was decreased when cells were incubated with $2000 \mu \mathrm{M}$ amantadine $\mathrm{HCl}$ (Fig. 1B). In addition, we also found that cell viability was suppressed when cells were incubated with amantadine $\mathrm{HCl}$ at doses $\geq 50 \mu \mathrm{M}$ for three days (Fig. 1B).

Lower doses of amantadine $\mathrm{HCl}(\leq 1000 \mu \mathrm{M})$ do not induce cell apoptosis in bovine cornea endothelial cells. To examine whether amantadine $\mathrm{HCl}$ induces apoptosis in bovine cornea endothelial cells, BCE C/D-1b cells were treated with various doses of amantadine $\mathrm{HCl}(0-2000 \mu \mathrm{M})$ or docetaxel (DTX, 10 and $100 \mathrm{nM}$ ) for $24 \mathrm{~h}$. Apoptotic cells were examined by Annexin V/propidium iodide (PI) staining and flow cytometry analysis. Experimental results indicated that lower doses of amantadine $\mathrm{HCl}(\leq 1000 \mu \mathrm{M})$ did not induce apoptosis, whereas higher dose of amantadine $\mathrm{HCl}(2000 \mu \mathrm{M})$ induced cell apoptosis in BCE C/D-1b cells (Fig. 2A,B). DTX is an anti-mitotic chemotherapeutic drug that induces cell apoptosis and arrests cell cycle progression $^{24}$; therefore, this was used as positive control. The activity of caspase 3/7, a marker of apoptosis ${ }^{25}$, was also examined. BCE C/D-1b cells were treated with various doses of amantadine $\mathrm{HCl}(0-2000 \mu \mathrm{M})$ for $24 \mathrm{~h}$. The activity of caspase 3/7 was analyzed using Caspase-Glo 3/7 assay kit. Our experimental results indicated that amantadine $\mathrm{HCl} 2000 \mu \mathrm{M}$ significantly increased the activity of caspase $3 / 7$, while lower doses $(0-1000 \mu \mathrm{M}) \mathrm{did}$ not (Fig. 2C).

Lower doses of amantadine $\mathrm{HCl}(\leq 100 \mu \mathrm{M})$ do not affect the progression of cell cycle, but doses of amantadine $\mathrm{HCl}$ at 200-1000 $\mu \mathrm{M}$ induce cell cycle arrest in G1 phase in bovine cornea endothelial cells. To examine whether amantadine $\mathrm{HCl}$ affected the progression of cell cycle in bovine cornea endothelial cells, BCE C/D-1b cells were treated with various doses of amantadine $\mathrm{HCl}(0-2000 \mu \mathrm{M})$ or DTX (10 and $100 \mathrm{nM}$ ) for $24 \mathrm{~h}$. The progression of cell cycle was measured by flow cytometry. As shown in Fig. 3, lower doses of amantadine $\mathrm{HCl}(\leq 100 \mu \mathrm{M})$ did not affect the progression of cell cycle; however, experimental results indicated that doses of amantadine $\mathrm{HCl}$ at $200-1000 \mu \mathrm{M}$ induced $\mathrm{G} 1$ arrest and decreased $\mathrm{S}$ proportion in BCE C/D-1b cells (Fig. 3). DTX was used as positive control.

Doses of amantadine $\mathrm{HCl}$ at 0-750 $\mu \mathrm{M}$ do not cause DNA damage but attenuate cell proliferation of bovine cornea endothelial cells. Since doses of amantadine $\mathrm{HCl}$ at $200-1000 \mu \mathrm{M}$ were found to induce $\mathrm{G} 1$ arrest in $\mathrm{BCE} \mathrm{C} / \mathrm{D}$-1b cells (Fig. 3), these doses of amantadine $\mathrm{HCl}$ were further examined to assess whether they affected DNA integrity, DNA synthesis and cell proliferation. To test the effect of amantadine $\mathrm{HCl}$ on DNA damage, the alkaline comet assay was employed to detect the single-strand DNA breaks. As shown in Fig. 4, doses of amantadine $\mathrm{HCl}$ lower than $1000 \mu \mathrm{M}(0-750 \mu \mathrm{M})$ had no significant effect on DNA damage visà-vis higher doses of amantadine $\mathrm{HCl}(1000-2000 \mu \mathrm{M}) . \mathrm{H}_{2} \mathrm{O}_{2}$ was used as positive control since it is a source of ROS which can cause DNA damage ${ }^{26}$. For the DNA synthesis, experimental results indicated that amantadine $\mathrm{HCl}$ significantly inhibited the EdU incorporation at doses $\geq 200 \mu \mathrm{M}$ (Fig. 5A,B). In addition, the results of CFSE cell proliferation assay showed that amantadine $\mathrm{HCl}$ attenuated cell proliferation at doses $\geq 750 \mu \mathrm{M}$ (Fig. 5C,D).

Higher doses of amantadine $\mathrm{HCl}(\geq 1000 \mu \mathrm{M})$ induce endothelial hyperpermeability. Endothelium maintains stromal deturgescence through barrier and pump functions. While the barrier function limits excessive fluid influx into the stroma from the anterior chamber, the fluid pump function counterbalances fluid leaks through the paracellular space ${ }^{27}$. Altered endothelial cell function and abnormalities or damage in the endothelial cell barrier might lead to corneal edema. To further examine whether amantadine $\mathrm{HCl}$ affects endothelial permeability, in vitro endothelial permeability was performed and the passage of FITC-dextran was examined. Experimental results indicated that doses of amantadine $\mathrm{HCl} \leq 750 \mu \mathrm{M}$ had no significant effect on 
A
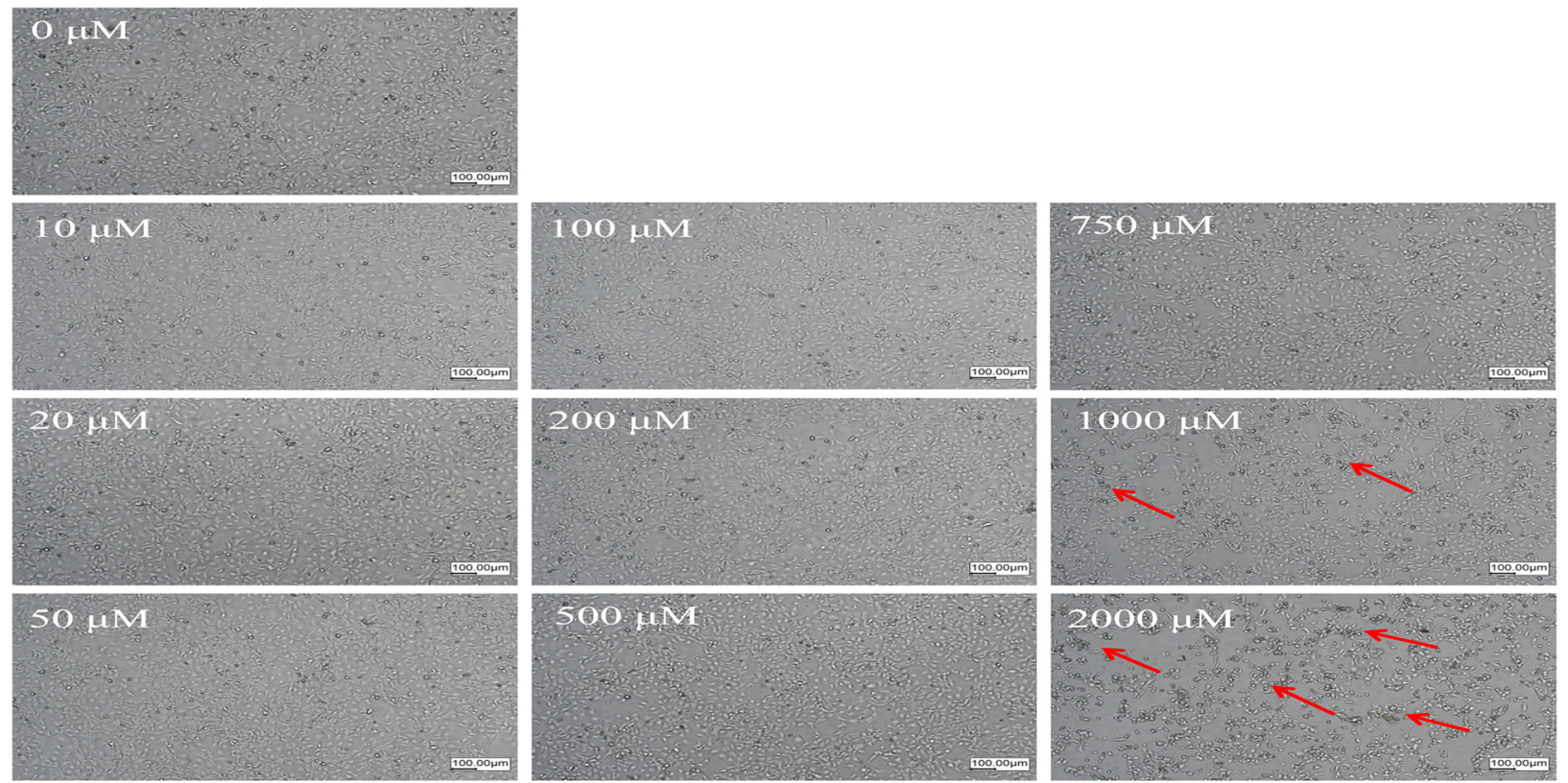

B

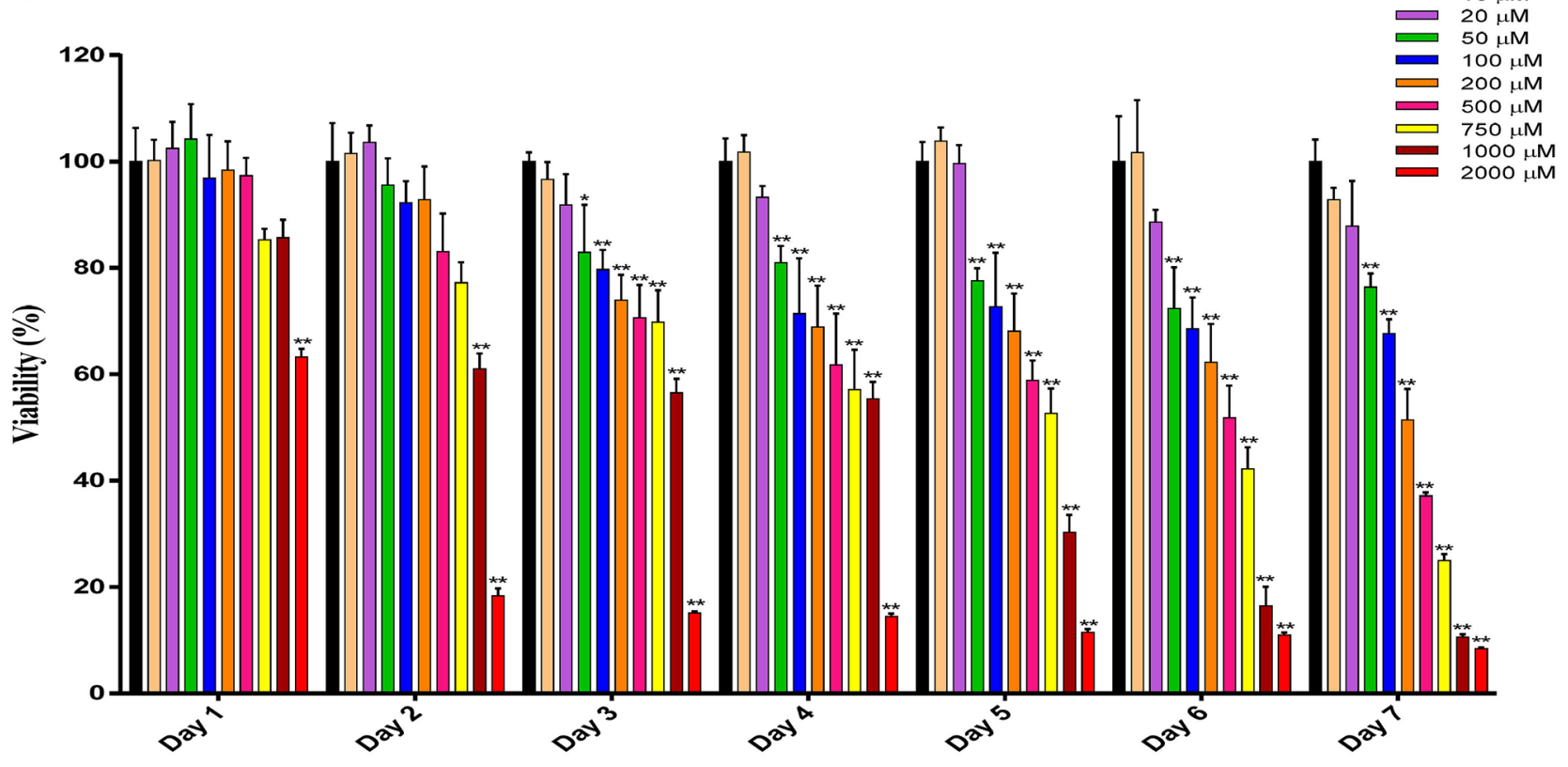

Figure 1. Effect of amantadine $\mathrm{HCl}$ on cell growth of bovine cornea endothelial cells. (A) BCE C/D-1b cells were treated with various doses of amantadine $\mathrm{HCl}(0-2000 \mu \mathrm{M})$ for $24 \mathrm{~h}$. Cell morphology was monitored by phase-contrast microscopy. The red arrow indicates dead cells that became detached and floated after treatment. Assays were carried out in triplicates, and the results are representative of three independent experiments. (B) $\mathrm{BCE} \mathrm{C} / \mathrm{D}-1 \mathrm{~b}$ cells were treated with various concentrations of amantadine $\mathrm{HCl}(0-2000 \mu \mathrm{M})$ for 1-7 days. Cell viability was examined by MTT assay. The data are presented as means \pm SD of three independent experiments. Statistical significance was represented as follows: ${ }^{*} \mathrm{p}<0.05$ or ${ }^{\star *} \mathrm{p}<0.01 \mathrm{vs}$. untreated control.

the permeability of FITC-dextran at $1 \mathrm{~h}$ compared to untreated control; however, higher doses of amantadine $\mathrm{HCl}(\geq 1000 \mu \mathrm{M})$ significantly increased cell permeability, indicating that $\geq 1000 \mu \mathrm{M}$ amantadine might lead to damage of the endothelial cell barrier (Fig. 6). DTX was used as positive control.

\section{Discussion}

Unlike bovine corneal endothelial cells ${ }^{28}$, human corneal endothelial cells do not regenerate in vivo and exhibit limited proliferative capability in vitro caused by contact-inhibited growth arrest at the G1 phase ${ }^{29}$. In addition, human corneal endothelial cells are not easy to obtain; therefore, in the present study, we tested the cytotoxic effect of amantadine $\mathrm{HCl}$ using bovine corneal endothelial cells. Our experimental results showed that acute toxicity of amantadine $\mathrm{HCl}$ on bovine cornea endothelial cells was not observed at doses $\leq 100 \mu \mathrm{M}$ for $24 \mathrm{~h}$; 

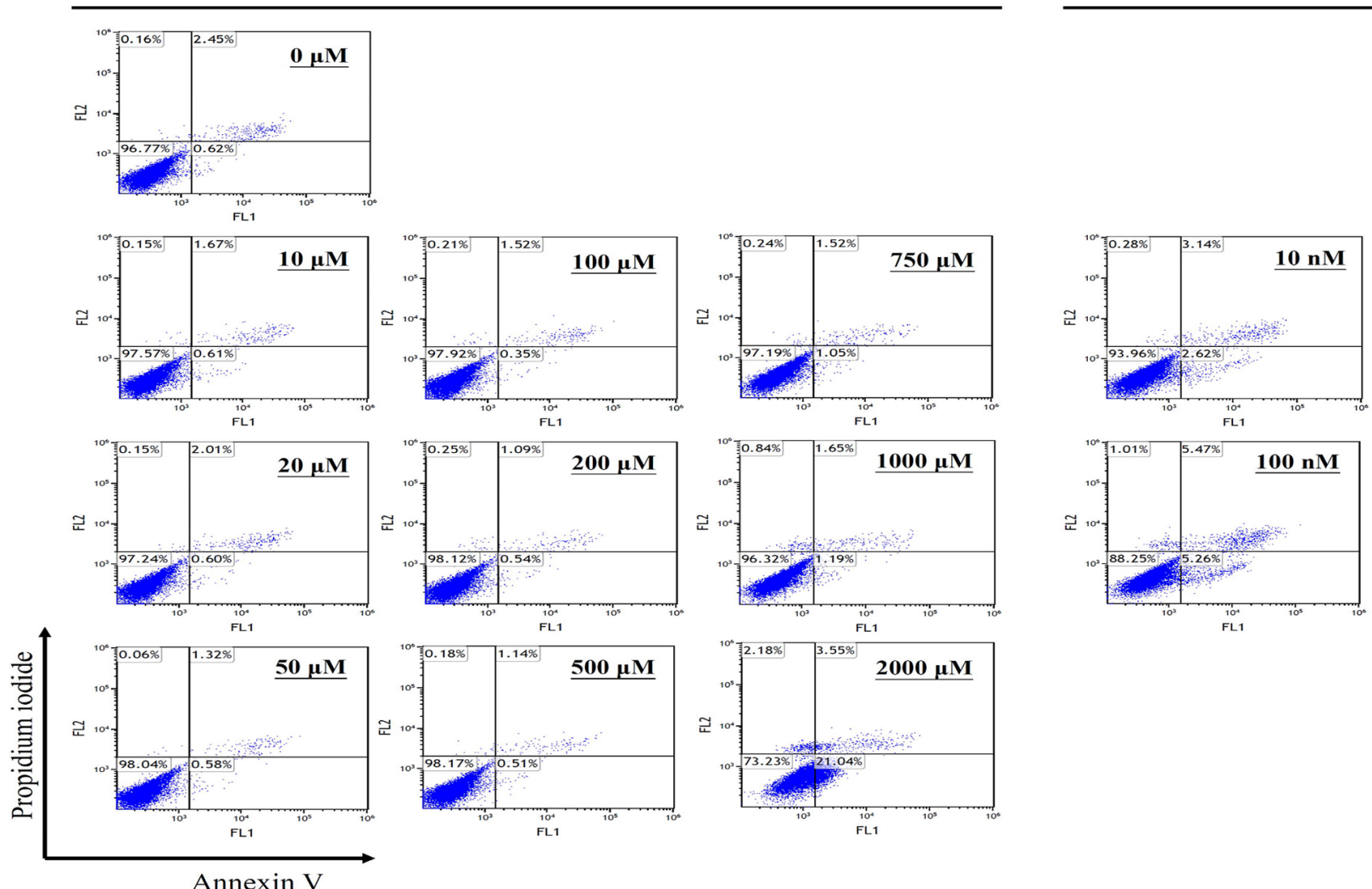

Annexin V

B

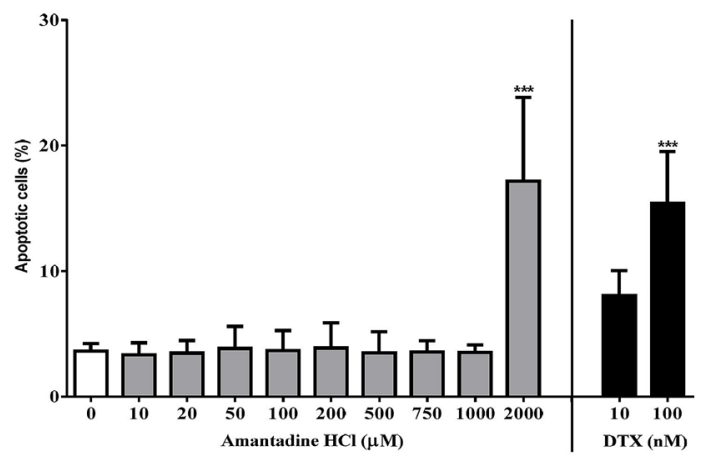

C

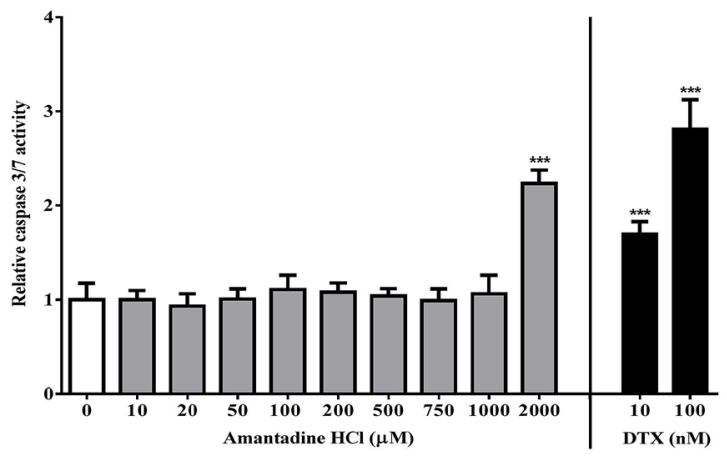

Figure 2. Effect of amantadine $\mathrm{HCl}$ on cell apoptosis of bovine cornea endothelial cells. BCE C/D-1b cells were treated with various doses of amantadine $\mathrm{HCl}(0-2000 \mu \mathrm{M})$ or DTX $(10$ and $100 \mathrm{nM})$ for $24 \mathrm{~h}$. Cells were stained with Annexin V and PI and assayed by flow cytometry. (A) The results are representative of three independent experiments. (B) Statistical analysis was carried out from three independent experiments. (C) The activity of caspase $3 / 7$ was analyzed by Caspase-Glo 3/7 assay kit. DTX was used as positive control. The data are presented as means \pm SD of three independent experiments. Statistical significance was represented as follows: ${ }_{* * *} \mathrm{p}<0.001$ vs. untreated control.

however, it was found that doses of amantadine $\mathrm{HCl} \geq 200 \mu \mathrm{M}$ induced cell cycle arrest at $\mathrm{G} 1$ phase and resulted in the inhibition of both DNA synthesis and cell proliferation.

A recent study indicated that incubation of bovine corneal samples with $200 \mu \mathrm{M}$ amantadine $\mathrm{HCl}$ for $6 \mathrm{~h}$ did not increase cell death compared with untreated control samples, but cell height was significantly increased compared to controls, which might result in cell death and reduce the density of corneal endothelial cells noted in patients on amantadine $\mathrm{HCl}$ therapy ${ }^{30}$. Notably, the experimental results indicated that higher doses of amantadine $\mathrm{HCl}(\geq 1000 \mu \mathrm{M})$ had significantly cytotoxicity with consistently toxic effects on bovine cornea endothelial cells including inhibiting cell growth and proliferation, inducing DNA damage and apoptosis, and increasing endothelial permeability. A previous study indicated that amantadine was transported principally across the blood-brain barrier by a saturable transport system with a one-half saturation concentration of about $1.0 \mathrm{mM}^{31}$. The mean amantadine concentrations in human brain tissue ranged from 48.2 to $386 \mu \mathrm{M}$ when the duration 
A
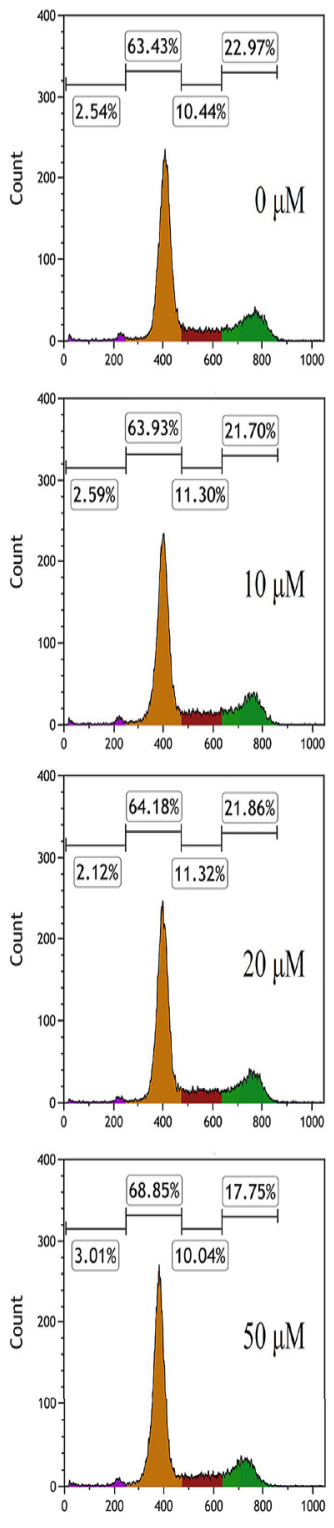
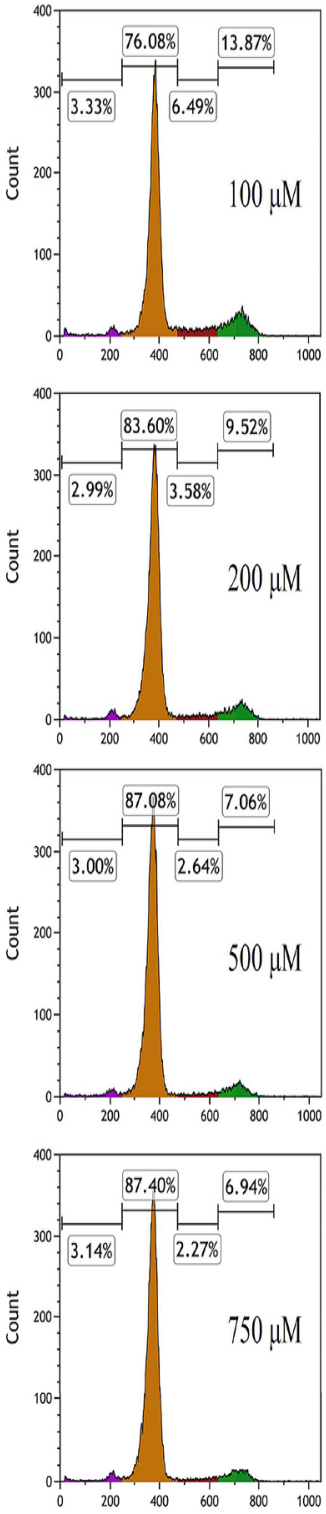
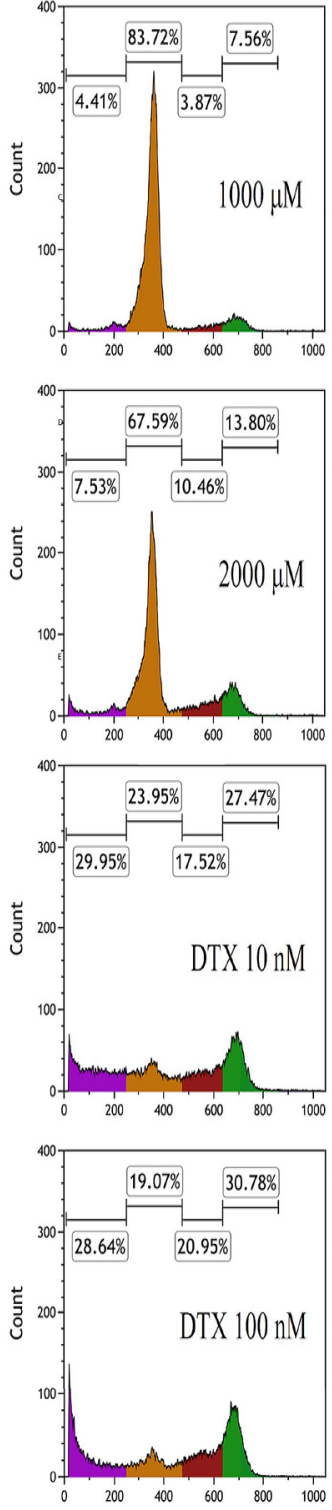

B

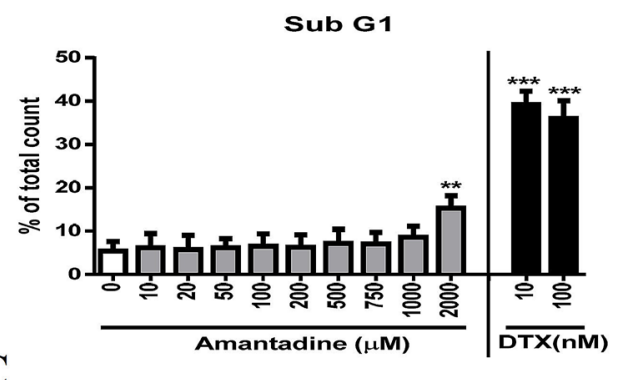

C

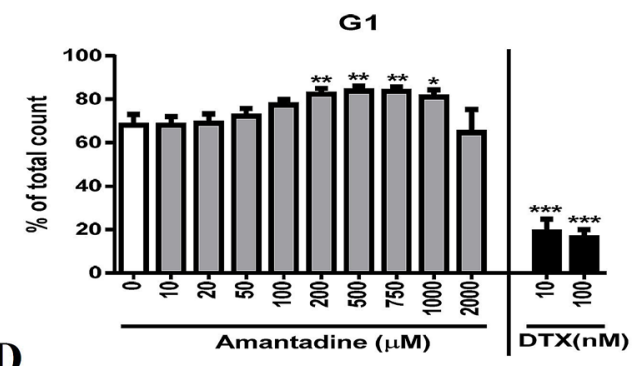

S

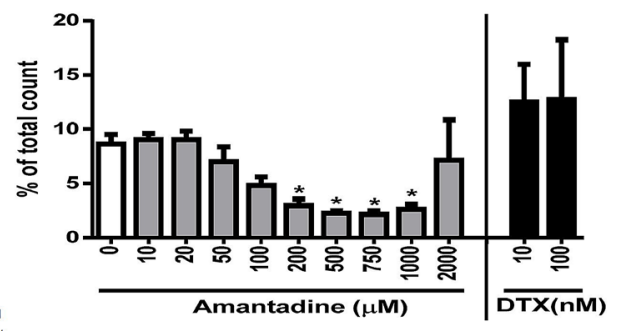

$\mathbf{E}$

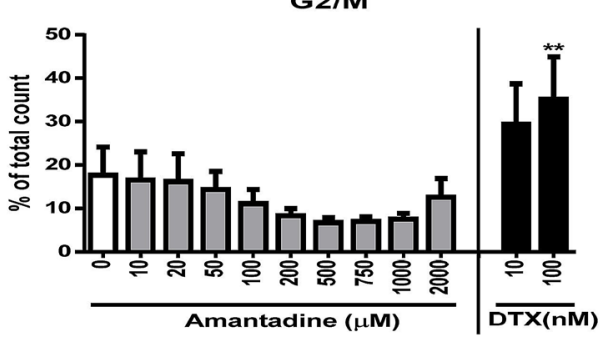

Figure 3. Effect of amantadine $\mathrm{HCl}$ on the progression of cell cycle of bovine cornea endothelial cells. $\mathrm{BCE}$ $\mathrm{C} / \mathrm{D}-1 \mathrm{~b}$ cells were treated with various concentrations of amantadine $\mathrm{HCl}(0-2000 \mu \mathrm{M})$ or DTX $(10$ and $100 \mathrm{nM}$ ) for $24 \mathrm{~h}$. Cells were fixed, stained with PI, and then assessed by flow cytometry. (A) The results are representative of three independent experiments. (B-E) Statistical analysis was carried out from three independent experiments. DTX was used as positive control. The data are presented as means \pm SD of three independent experiments. Statistical significance was represented as follows: ${ }^{*} p<0.05,{ }^{* *} p<0.01$ or ${ }^{* *} p<0.001$ vs. untreated control.

of treatment was $\geq 10$ days and the drug-free time $\leq 3$ days ${ }^{12}$. Corneal endothelium has been thought to be nonmitotic cells that have no potential in regeneration and reparation ${ }^{32-34}$. Accumulated doses of amantadine $\mathrm{HCl}$ might cause cornea edema. In addition, a nationwide cohort study of patients with PD in Taiwan indicated that amantadine $\mathrm{HCl}$ increases the risk of cornea edema in a concentration-dependent manner (a hazard ratio of 2.05 for a moderate dose (2000-4000 mg) and 2.84 for a high dose (4000 mg $)^{11}$; therefore, to judge the toxic effect of amantadine $\mathrm{HCl}$, the exact concentration of amantadine $\mathrm{HCl}$ in the cornea should be further examined.

Previous studies pointed out that the CTG18.1 repeat expansion might reduce TCF4 gene expression ${ }^{35}$ and Hessen et al. examined the copy number of CTG18.1 trinucleotide repeat in the TCF4 gene by an amantadine $\mathrm{HCl}$-associated corneal edema patient ${ }^{36}$. Although they did not find the change on the copy number of CTG18.1 trinucleotide repeat in the TCF4 gene, genetic variation remains an important issue that might create sensitivity to amantadine $\mathrm{HCl}$ treatment, leading to corneal edema. In the present study, although the cytotoxic dosages of amantadine $\mathrm{HCl}$ were much higher than in clinical situations, accumulated doses of amantadine $\mathrm{HCl}$ might still pose risk to cause corneal edema in patients with rare genetic variations. 
A

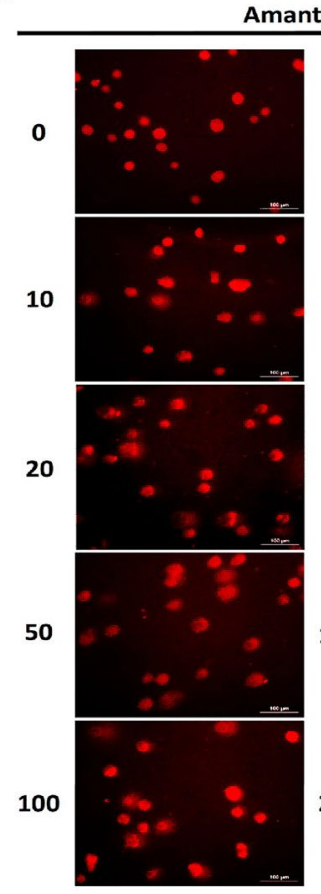

Amantadine $(\mu \mathrm{M})$

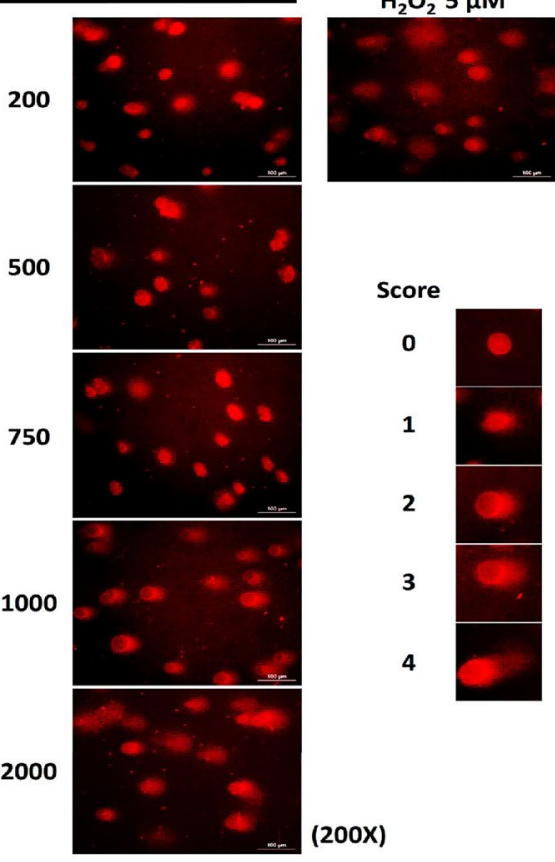

B

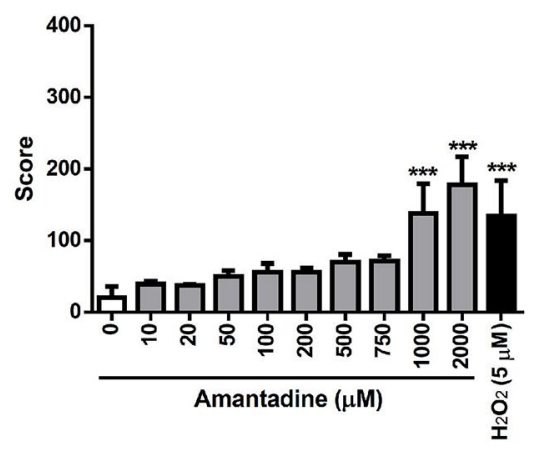

Figure 4. Effect of amantadine $\mathrm{HCl}$ on the $\mathrm{DNA}$ integrity in bovine cornea endothelial cells. BCE C/D-1b cells were treated with different concentrations of amantadine $\mathrm{HCl}(0-2000 \mu \mathrm{M})$ or $\mathrm{H}_{2} \mathrm{O}_{2}(5 \mu \mathrm{M})$ for $24 \mathrm{~h}$. The DNA damage of cells was measured by alkaline comet assay method. One hundred cells per slide were scored into classes $0,1,2,3$ and 4 respectively according to the relative intensity of fluorescence in the tail. (A) The presentative images of three independent experiments. (B) Extent of DNA damage was scored and the statistical significance was represented as follows: ${ }^{* *} \mathrm{p}<0.01$ vs. untreated control.

There are several limitations in the present study. Firstly, because human cornea endothelial cells are not easy to obtain, bovine cornea endothelial cells were used to examine the toxic effect of amantadine $\mathrm{HCl}$, and there might well be differences between bovine and human cornea endothelial cells. Secondly, further experiments could not proceed due to the lack of antibodies to bovine cells; thirdly, an in vitro experimental model could not achieve the cumulative dose of amantadine $\mathrm{HCl}$ in vivo; fourthly, the in vitro cytotoxic assays used in this study could not fully represent the real saturation of corneal edema; and finally, the duration of amantadine treatment in the present study might not represent the effects of the drug in real life due to edema formation in a physiological sense manifesting over time.

To our knowledge, this is the first study to successfully examine the cytotoxic effects of amantadine $\mathrm{HCl}$ using cornea endothelial cells, having performed the evaluation of these on cell growth, proliferation, apoptosis, and endothelial permeability as well as DNA integrity in bovine cornea endothelial cells. Our experimental results indicated that no cytotoxic effect of amantadine $\mathrm{HCl}$ on bovine cornea endothelial cells was observed at doses $\leq 100 \mu \mathrm{M}$ for $24 \mathrm{~h}$. However, doses of amantadine $\mathrm{HCl} \geq 200 \mu \mathrm{M}$ induced cell cycle arrest at G1 phase and resulted in the inhibition of both DNA synthesis and cell proliferation in bovine cornea endothelial cells after 24-h treatment. Doses of amantadine $\mathrm{HCl} \geq 1000 \mu \mathrm{M}$ had cytotoxic effects on bovine cornea endothelial cells including inhibiting cell growth and proliferation, inducing DNA damage and apoptosis, and increasing endothelial permeability after 24 -h treatment. In a 72 -h treatment, doses of amantadine $\mathrm{HCl} \geq 50 \mu \mathrm{M}$ attenuated cell growth on bovine cornea endothelial cells. The cytotoxic dosages of amantadine $\mathrm{HCl}$ on bovine cornea endothelial cells might provide a hint for further evaluating the toxic effect of amantadine on corneal edema.

\section{Material and methods}

Reagents. Dulbecco's modified Eagle's medium (DMEM), penicillin and streptomycin were obtained from Corning Cellgro (Manassas, VA, USA). Fetal bovine serum (FBS) was obtained from Gibco-BRL (Life Technologies, Grand Island, NY, USA). Amantadine HCl (A1260; Molecular Weight: 187.7), 3-(4,5-dimethylthiazol-2-yl)-2,5-diphenyltetrazolium bromide (MTT), PI, Triton X-100, ribonuclease A (RNase A), DTX, normal melting point agarose, low melting point agarose and fluorescein isothiocyanate (FITC)-dextran (40 kDa) were obtained from Sigma (St. Louis, MO, USA). Caspase-Glo 3/7 assay kit was purchased from Promega (Madison, WI, USA). Alexa Fluor 488 Annexin V/Dead Cell Apoptosis kit and Click-iT EdU Alexa Fluor 488 flow cytometry assay kit were purchased from Thermo Fisher Scientific (Waltham, MA, USA). CFSE cell-division tracker kit was obtained from BioLegend (San Diego, CA, USA). 
A
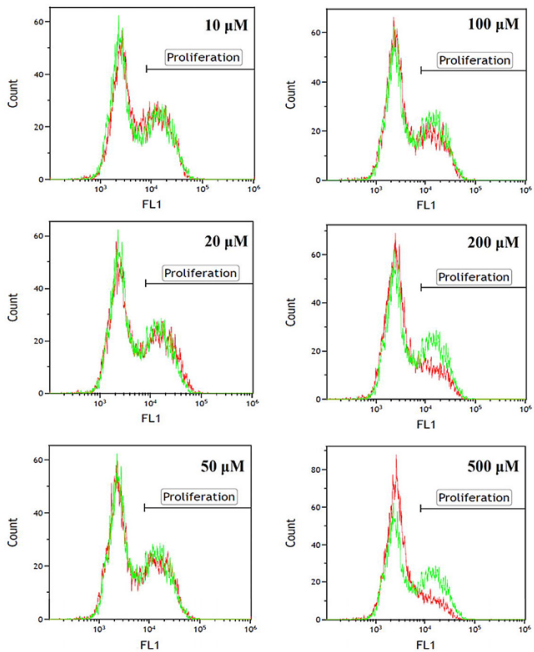

C
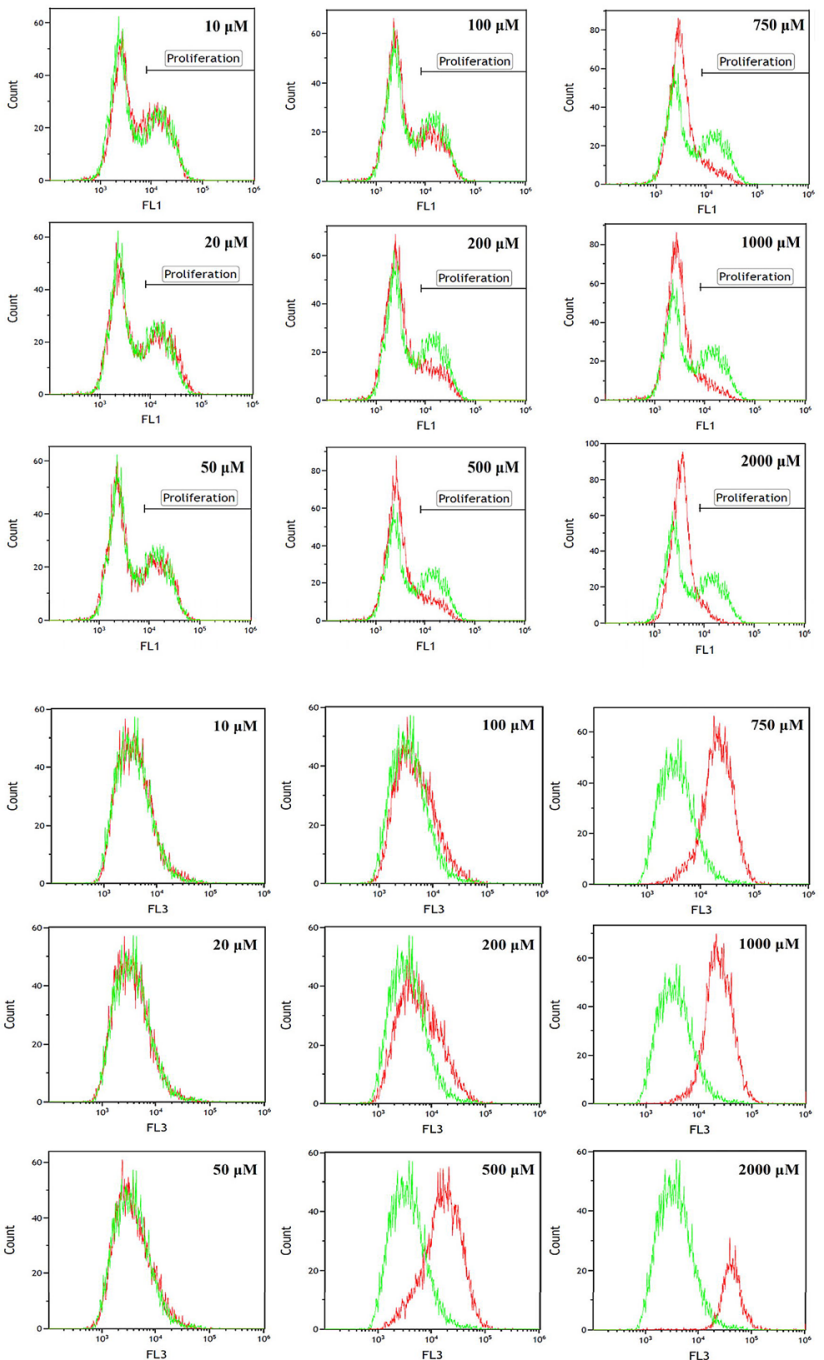

B

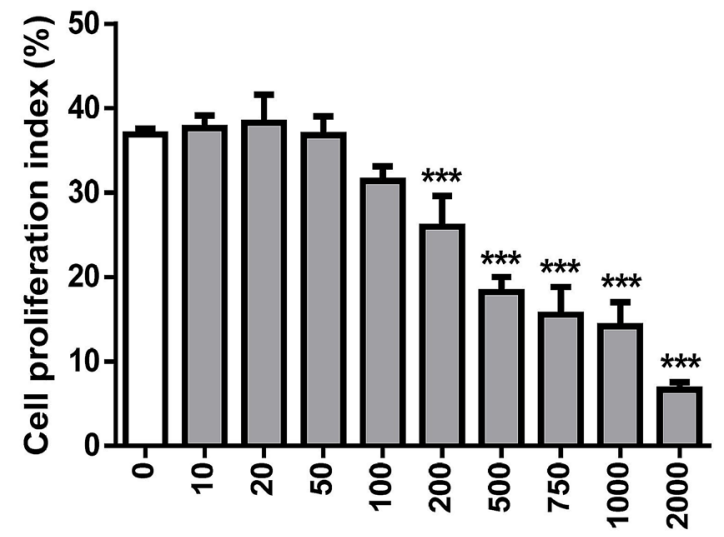

Amantadine $(\mu \mathrm{M})$

D

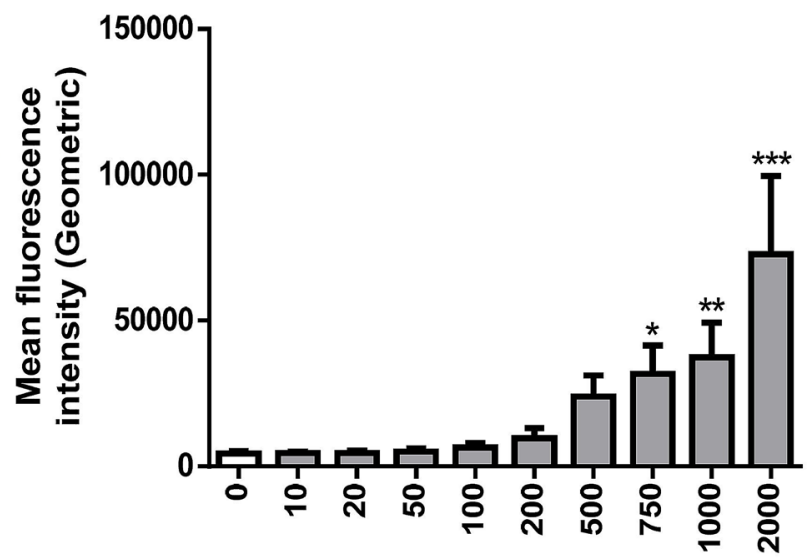

Amantadine $(\mu \mathrm{M})$

Figure 5. Effect of amantadine $\mathrm{HCl}$ on cell proliferation in bovine cornea endothelial cells. BCE C/D-1b cells were treated with different concentrations of amantadine $\mathrm{HCl}(0-2000 \mu \mathrm{M})$ for $24 \mathrm{~h}$. (A) The DNA synthesis was examined by EdU incorporation assay. Overlay of the histograms of untreated cells (green) and cells treated with amantadine $\mathrm{HCl}$ (red). (B) The cell proliferation index was quantified and the statistical significance was represented as follows: ${ }^{* *} \mathrm{p}<0.01$ vs. untreated control. BCE C/D-1b cells were labeled with $1 \mu \mathrm{M}$ CFSE for $10 \mathrm{~min}$ and then treated with different concentrations of amantadine $\mathrm{HCl}(0-2000 \mu \mathrm{M})$ for seven days. (C) The results are representative of three independent experiments. The CFSE histograms of amantadine $\mathrm{HCl}$ treated cells (red) were overlaid with untreated cells (green). (D) Statistical analysis was carried out from three independent experiments. Data are presented as means \pm SD and the statistical significance was represented as follows: ${ }^{\star} \mathrm{p}<0.05,{ }^{\star *} \mathrm{p}<0.01$ and ${ }^{\star * *} \mathrm{p}<0.001$ vs. untreated control.

Cell culture. The bovine cornea endothelial cell line, BCE C/D-1b cell, was purchased from American Type Culture Collection (CRL-2048, Manassas, VA, USA). BCE C/D-1b cells were cultured in DMEM supplemented with $10 \%$ heat-inactivated FBS, $100 \mathrm{U} / \mathrm{mL}$ penicillin and $100 \mathrm{U} / \mathrm{mL}$ streptomycin in a humidified atmosphere of $5 \% \mathrm{CO}_{2}$ at $37^{\circ} \mathrm{C}$. The cells were used for experiments at passages 6-20. Amantadine $\mathrm{HCl}$ was dissolved in PBS to prepare a $50 \mathrm{mg} / \mathrm{mL}(266.3 \mathrm{mM})$ stock solution and stored at $-20^{\circ} \mathrm{C}$. For the preparation of working solution, amantadine $\mathrm{HCl}$ was diluted into $10 \mathrm{mM}$ using complete DMEM medium. The osmolarity of the incubation media with amantadine $\mathrm{HCl}$ treatments $(0-2000 \mu \mathrm{M})$ was detected by micro-osmometer (Model 210, Fiske, Norwood, MA, USA) and the results showed that all incubation media were isotonic solutions $(330 \pm 2 \mathrm{mOsm} /$ $\mathrm{kg})$.

Cell viability assay. Cell viability was examined by the MTT colorimetric assay. A total of $1 \times 10^{4}$ cells was seeded in 96-well plates and cultured overnight for attachment. Various concentrations of amantadine $\mathrm{HCl}$ $(0-2000 \mu \mathrm{M})$ were treated for 1 to 7 days. Half of the cultured medium was replaced with fresh amantadine $\mathrm{HCl}$ every two days. Thereafter, $0.1 \mathrm{mg}$ MTT was dissolved in DPBS and then added into each well and incubated 

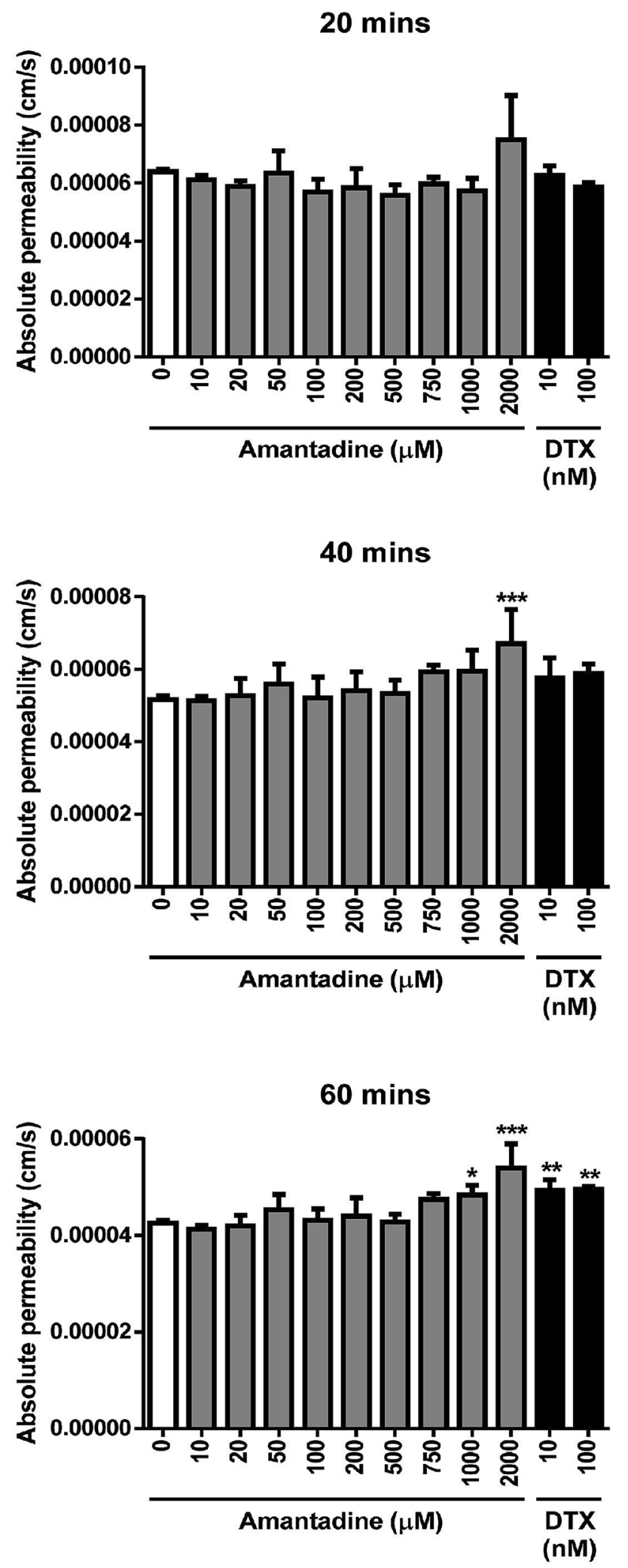

Figure 6. Effect of amantadine $\mathrm{HCl}$ on endothelial permeability in bovine cornea endothelial cells. BCE $\mathrm{C} / \mathrm{D}-1 \mathrm{~b}$ cells were seeded in the upper chamber of $0.4 \mu \mathrm{m}$ transwell inserts and treated with different concentrations of amantadine $\mathrm{HCl}(0-2000 \mu \mathrm{M})$ or DTX (10 and $100 \mathrm{nM})$ for $24 \mathrm{~h}$. Afterward, FITC-dextran $(1 \mathrm{mg} / \mathrm{mL})$ was added into the upper chamber, then the lower chamber media was collected after $0,20,40$ or $60 \mathrm{~min}$, and fluorescent intensity was measured (ex: $485 \mathrm{~nm}$; em: $535 \mathrm{~nm}$ ) using a fluorescence plate reader. The absolute permeability was presented as means \pm SD of three independent experiments. The statistical significance was represented as follows: ${ }^{\star} \mathrm{p}<0.05,{ }^{\star *} \mathrm{p}<0.01$ and ${ }^{\star * *} \mathrm{p}<0.001$ vs. untreated control. 
for $4 \mathrm{~h}$ at $37^{\circ} \mathrm{C}$. Afterward, the formed formazan crystals were solubilized using $100 \mu \mathrm{L}$ hydrochloric acid-isopropanol (1 portion of $4 \mathrm{~N} \mathrm{HCl} 100$ portion of isopropanol). After $20 \mathrm{~min}$ of solubilization, the absorbance of $570 \mathrm{~nm}$ was measured with a microplate reader (BioTek Instruments, Winooski, VT, USA).

Apoptosis assay. The apoptotic cells were detected using Annexin V and PI staining and the method was modified from a previous study ${ }^{37}$. Briefly, BCE C/D-1b cells were treated with different doses of amantadine $\mathrm{HCl}$ $(0-2000 \mu \mathrm{M})$ for $24 \mathrm{~h}$. Cells were stained with Alexa Fluor 488 Annexin V and PI in binding buffer according to the manufacturer's protocol (Thermo Fisher Scientific, Waltham, MA, USA) and analyzed by FC500 flow cytometer (Beckman-Coulter, Fullerton, CA, USA). A total of ten thousand events were collected per sample, and data were acquired and processed using CXP analysis software (Beckman-Coulter, Fullerton, CA, USA).

Caspase 3/7 activity assay. The caspase 3/7 activity assay was used to detect the activity of caspase 3 or 7 in the cells and the method was modified from a previous study ${ }^{37}$. Briefly, a total of $5 \times 10^{3} \mathrm{BCE} C / \mathrm{D}-1 \mathrm{~b}$ cells were seeded in a 96-well white plate and allowed to acclimatize overnight. Afterward, cells were treated with different doses of amantadine $\mathrm{HCl}(0-2000 \mu \mathrm{M})$ for $24 \mathrm{~h}$. Thereafter, Caspase-Glo 3/7 reagent was added to each well and gently mixed using a plate shaker at 300-500 rpm for $30 \mathrm{~s}$, and then samples were incubated for $30 \mathrm{~min}$ at RT. Enzyme activity was directly proportional to luminescence. The luminescence intensity was detected by a luminescence microplate reader (BioTek Instruments, Winooski, VT, USA), and the data were normalized relative to the caspase $3 / 7$ activity of cells treated with DMSO alone.

Cell cycle analysis. The cell cycle analysis was detected DNA content using flow cytometry and the method was modified from a previous study ${ }^{38}$. Briefly, BCE C/D-1b cells were treated with different doses of amantadine $\mathrm{HCl}(0-2000 \mu \mathrm{M})$ for $24 \mathrm{~h}$. Cells were trypsinized, washed twice by cold PBS, and fixed in $70 \%$ ethanol overnight at $4^{\circ} \mathrm{C}$. After fixation, cells were washed twice with PBS and then incubated in PBS containing PI, RNase $\mathrm{A}$ and Triton X-100 at $4{ }^{\circ} \mathrm{C}$ for $30 \mathrm{~min}$. The cell cycle phase distribution was assessed by FC500 flow cytometer (Beckman-Coulter, Fullerton, CA, USA). Data were analyzed by Kaluza analysis software (Beckman Coulter, Brea, CA, USA).

Comet assay. The alkaline comet assay was used for the detection of DNA single-strand breaks and performed according to our previous study ${ }^{39}$. Briefly, plain glass slides were pre-covered with $1 \%$ normal melting point agarose in PBS ( $\mathrm{pH} 7.4$ ) and allowed to dry on a flat surface at room temperature. BCE C/D-1b cells were treated with different doses of amantadine $\mathrm{HCl}(0-2000 \mu \mathrm{M})$ for $24 \mathrm{~h}$. A total of $10^{5}$ cells were gently mixed with $0.5 \%$ low melting point agarose in PBS ( $\mathrm{pH} 7.4$ ), rapidly layered onto the precoated slides, and covered with a coverslip. After removing the cover slip, cells were immersed in a freshly made alkaline lysis solution $(2.5 \mathrm{M}$ $\mathrm{NaCl}, 100 \mathrm{mM} \mathrm{Na}{ }_{2} \mathrm{EDTA}, 10 \mathrm{mM}$ Tris and $1 \%$ Triton $\mathrm{X}-100$ at $\left.\mathrm{pH} 10\right)$ at $4{ }^{\circ} \mathrm{C}$ for $1 \mathrm{~h}$. Afterward, the slides were placed in an electrophoresis tank containing $0.3 \mathrm{M} \mathrm{NaOH}$ and $1 \mathrm{mM} \mathrm{Na}_{2}$ EDTA and run electrophoresis $(30 \mathrm{~V}$, $300 \mathrm{~mA}$ ) for $15 \mathrm{~min}$ at $4{ }^{\circ} \mathrm{C}$. Slides were soaked in a cold neutralizing buffer $(400 \mathrm{mM}$ Tris buffer, pH 7.0$)$ at $4{ }^{\circ} \mathrm{C}$ for $5 \mathrm{~min}$, stained with PI $(2.5 \mu \mathrm{g} / \mathrm{mL})$, and analyzed by fluorescence microscopy. One hundred cells per slide were scored into classes $0,1,2,3$ and 4 respectively according to the relative intensity of fluorescence in the tail.

Cell proliferation assay. For cell proliferation, this was evaluated at two levels: DNA synthesis and cell division using EdU incorporation assay and CFSE cell-division tracking respectively. For the detection of DNA synthesis, BCE C/D-1b cells were treated with different doses of amantadine $\mathrm{HCl}(0-2000 \mu \mathrm{M})$ for $24 \mathrm{~h}$ and then $5 \mu \mathrm{M}$ EdU was added into the cell culture medium for $6 \mathrm{~h}$. The cellular EdU content was measured by flow cytometry. For the detection of cell division, BCE C/D-1b cells were labeled with $1 \mu \mathrm{M}$ CFSE for 10 min at $37^{\circ} \mathrm{C}$ and protected from light. Cells were washed three times with DMEM containing 10\% FBS and then treated with different doses of amantadine $\mathrm{HCl}(0-2000 \mu \mathrm{M})$ for 7 days. The dividing cells were detected by flow cytometry.

In vitro permeability assay. Cell permeability assay was modified according to a previous study ${ }^{40}$. Briefly, 12-transwell inserts $(0.4 \mu \mathrm{m}$ polyester membrane, Corning, New York, USA) were coated with collagen type I $\left(5 \mu \mathrm{g} / \mathrm{cm}^{2}\right.$, Corning, New York, USA) at room temperature for $30 \mathrm{~min}$ and then incubated at $37^{\circ} \mathrm{C}$ for $2 \mathrm{~h}$. A total of $2.5 \times 10^{4} \mathrm{BCE} \mathrm{C/D-1b}$ cells were seeded into the inserts and allowed to acclimatize overnight. Cells were treated with various doses of amantadine $\mathrm{HCl}(0-2000 \mu \mathrm{M})$ or DTX $(10$ and $100 \mathrm{nM})$ for $24 \mathrm{~h}$ and then treated with $1 \mathrm{mg} / \mathrm{mL}$ FITC-dextran on the upper chamber. $100 \mu \mathrm{L}$ samples were taken after 0,20 , 40 or 60 min respectively from the lower chamber, and fluorescent intensity was measured (ex: $485 \mathrm{~nm}$; em: $535 \mathrm{~nm}$ ) using a fluorescence plate reader (Epoch, Biotek Instruments, USA). The removed volume was replaced by fresh medium. The absolute permeability $\mathrm{P}[\mathrm{cm} / \mathrm{s}]$ was calculated by the following equation.

$$
P=[\mathrm{C}(\mathrm{t})-\mathrm{C}(\mathrm{t} 0)] \cdot \mathrm{V}) /(\mathrm{A} \cdot \mathrm{t} \cdot \mathrm{C} 0)
$$

$\mathrm{C}(\mathrm{t})$ : FITC-dextran concentration $(\mu \mathrm{g} / \mathrm{mL})$ at time point selected for calculation; $\mathrm{C}(\mathrm{t} 0)$ : FITC-dextran concentration $(\mu \mathrm{g} / \mathrm{mL})$ at $0 \mathrm{~min}$; V: volume $\left(\mathrm{cm}^{3}\right)$ in the lower chamber; A: surface of transwell membrane $\left(\mathrm{cm}^{2}\right) ; \mathrm{t}$ : duration of the flux (s); C0: initial FITC-dextran concentration $(\mu \mathrm{g} / \mathrm{mL})$ in the upper chamber.

There are several limitations in the present study. Firstly, because human cornea endothelial cells are not easy to obtain, bovine cornea endothelial cells were used to examine the toxic effect of amantadine $\mathrm{HCl}$, and there might well be differences between bovine and human cornea endothelial cells. Secondly, further experiments could not proceed due to the lack of antibodies to bovine cells; thirdly, an in vitro experimental model could not achieve the cumulative dose of amantadine $\mathrm{HCl}$ in vivo; fourthly, the in vitro cytotoxic assays used in this 
study could not fully represent the real saturation of corneal edema; and finally, the duration of amantadine treatment in the present study might not represent the effects of the drug in real life due to edema formation in a physiological sense manifesting over time.

Statistical analysis. All data are expressed as means \pm SD. Each value is the mean of three independent experiments. Statistical analysis was assessed via one-way ANOVA followed by Tukey post-hoc test using IBM SPSS Statistics v.19 (IBM Corp., Armonk, NY, USA), and the significant difference was set at ${ }^{*} \mathrm{p}<0.05 ;{ }^{* *} \mathrm{p}<0.01$; ${ }^{* * *} \mathrm{p}<0.001$.

Received: 25 March 2021; Accepted: 1 September 2021

Published online: 16 September 2021

\section{References}

1. Hubsher, G., Haider, M. \& Okun, M. S. Amantadine: The journey from fighting flu to treating Parkinson disease. Neurology 78, 1096-1099. https://doi.org/10.1212/WNL.0b013e31824e8f0d (2012).

2. Schwab, R. S., England, A. C. Jr., Poskanzer, D. C. \& Young, R. R. Amantadine in the treatment of Parkinson's disease. JAMA 208, $1168-1170$ (1969).

3. Schwab, R. S. \& England, A. C. Jr. Amantadine HCL (Symmetrel) and its relation to Levo-Dopa in the treatment of Parkinson's disease. Trans. Am. Neurol. Assoc. 94, 85-90 (1969).

4. Crosby, N., Deane, K. H. \& Clarke, C. E. Amantadine in Parkinson’s disease. Cochrane Database Syst. Rev. 2, 003468. https://doi. org/10.1002/14651858.CD003468 (2003).

5. Lin, C. C. \& Chen, W. C. Treatment effectiveness of amantadine against dengue virus infection. Am. J. Case Rep. 17, 921-924. https://doi.org/10.12659/AJCR.901014 (2016).

6. Blazquez, A. B., Martin-Acebes, M. A. \& Saiz, J. C. Inhibition of west Nile virus multiplication in cell culture by anti-parkinsonian drugs. Front. Microbiol. 7, 296. https://doi.org/10.3389/fmicb.2016.00296 (2016).

7. Generali, J. A. \& Cada, D. J. Amantadine: Multiple sclerosis-related fatigue. Hosp. Pharm. 49, 710-712. https://doi.org/10.1310/ hpj4908-710 (2014).

8. Takeda, M., Pekosz, A., Shuck, K., Pinto, L. H. \& Lamb, R. A. Influenza a virus M2 ion channel activity is essential for efficient replication in tissue culture. J. Virol. 76, 1391-1399. https://doi.org/10.1128/jvi.76.3.1391-1399.2002 (2002).

9. Raupp-Barcaro, I. F., Vital, M. A., Galduroz, J. C. \& Andreatini, R. Potential antidepressant effect of amantadine: A review of preclinical studies and clinical trials. Braz. J. Psychiatry 40, 449-458. https://doi.org/10.1590/1516-4446-2017-2393 (2018).

10. Hayden, F. G., Minocha, A., Spyker, D. A. \& Hoffman, H. E. Comparative single-dose pharmacokinetics of amantadine hydrochloride and rimantadine hydrochloride in young and elderly adults. Antimicrob. Agents Chemother. 28, 216-221. https://doi.org/ 10.1128/aac.28.2.216 (1985).

11. Lee, P. Y. et al. Amantadine use as a risk factor for corneal edema: A nationwide cohort study in Taiwan. Am. J. Ophthalmol. 171, 122-129. https://doi.org/10.1016/j.ajo.2016.08.034 (2016).

12. Kornhuber, J. et al. Therapeutic brain concentration of the NMDA receptor antagonist amantadine. Neuropharmacology 34, 713-721. https://doi.org/10.1016/0028-3908(95)00056-c (1995).

13. Hesselink, M. B., De Boer, B. G., Breimer, D. D. \& Danysz, W. Brain penetration and in vivo recovery of NMDA receptor antagonists amantadine and memantine: A quantitative microdialysis study. Pharm. Res. 16, 637-642. https://doi.org/10.1023/a:1018856020 583 (1999).

14. Beran, M., Okyere, B. \& Vova, J. Amantadine-induced corneal edema in a pediatric neuro-oncology patient: A case report. $P M R$ 10, 1122-1124. https://doi.org/10.1016/j.pmrj.2018.03.007 (2018).

15. Chang, K. C., Kim, M. K., Wee, W. R. \& Lee, J. H. Corneal endothelial dysfunction associated with amantadine toxicity. Cornea 27, 1182-1185. https://doi.org/10.1097/ICO.0b013e318180e526 (2008).

16. Deogaonkar, M., Wilson, K. \& Vitek, J. Amantadine induced reversible corneal edema. J. Clin. Neurosci. 18, 298-299. https://doi. org/10.1016/j.jocn.2010.06.010 (2011).

17. Esquenazi, S. Bilateral reversible corneal edema associated with amantadine use. J. Ocul. Pharmacol. Ther. 25, 567-570. https:// doi.org/10.1089/jop.2009.0029 (2009).

18. Ghaffariyeh, A. \& Honarpisheh, N. Amantadine-associated corneal edema. Parkinson. Relat. Disord. 16, 427. https://doi.org/10. 1016/j.parkreldis.2010.02.013 (2010).

19. Kim, Y. E. et al. Amantadine induced corneal edema in a patient with primary progressive freezing of gait. J. Mov. Disord. 6, 34-36. https://doi.org/10.14802/jmd.13008 (2013).

20. Kubo, S., Iwatake, A., Ebihara, N., Murakami, A. \& Hattori, N. Visual impairment in Parkinson's disease treated with amantadine: Case report and review of the literature. Parkinson. Relat. Disord. 14, 166-169. https://doi.org/10.1016/j.parkreldis.2007.03.003 (2008).

21. Pond, A., Lee, M. S., Hardten, D. R., Harrison, A. R. \& Krachmer, J. H. Toxic corneal oedema associated with amantadine use. Br. J. Ophthalmol. 93(281), 413. https://doi.org/10.1136/bjo.2007.135731 (2009).

22. Yang, Y., Teja, S. \& Baig, K. Bilateral corneal edema associated with amantadine. CMAJ 187, 1155-1158. https://doi.org/10.1503/ cmaj.140542 (2015).

23. Feizi, S. Corneal endothelial cell dysfunction: Etiologies and management. Ther. Adv. Ophthalmol. 10, 2515841418815802. https:// doi.org/10.1177/2515841418815802 (2018)

24. Shi, J. \& Mitchison, T. J. Cell death response to anti-mitotic drug treatment in cell culture, mouse tumor model and the clinic. Endocr. Relat. Cancer 24, T83-T96. https://doi.org/10.1530/ERC-17-0003 (2017).

25. Elmore, S. Apoptosis: A review of programmed cell death. Toxicol. Pathol. 35, 495-516. https://doi.org/10.1080/019262307013203 37 (2007).

26. Driessens, N. et al. Hydrogen peroxide induces DNA single- and double-strand breaks in thyroid cells and is therefore a potential mutagen for this organ. Endocr. Relat. Cancer 16, 845-856. https://doi.org/10.1677/ERC-09-0020 (2009).

27. Srinivas, S. P. Dynamic regulation of barrier integrity of the corneal endothelium. Optom. Vis. Sci. 87, E239-254. https://doi.org/ 10.1097/OPX.0b013e3181d39464 (2010).

28. Hyldahl, L., Auer, G. \& Sundelin, B. A novel method to establish primary cultures of bovine corneal endothelial cells. Cell Biol. Int. Rep. 6, 523-528. https://doi.org/10.1016/0309-1651(82)90124-2 (1982).

29. Liu, Y. et al. Human corneal endothelial cells expanded in vitro are a powerful resource for tissue engineering. Int. J. Med. Sci. 14, 128-135. https://doi.org/10.7150/ijms.17624 (2017).

30. Dudley, C. E., Morell, A. J., Duffey, M. E. \& Patel, S. P. Effects of amantadine on corneal endothelium. Exp. Eye Res. 181, 208-212. https://doi.org/10.1016/j.exer.2019.02.010 (2019).

31. Spector, R. Transport of amantadine and rimantadine through the blood-brain barrier. J. Pharmacol. Exp. Ther. 244, 516-519 (1988). 
32. Joyce, N. C. Proliferative capacity of corneal endothelial cells. Exp. Eye Res. 95, 16-23. https://doi.org/10.1016/j.exer.2011.08.014 (2012).

33. Mimura, T., Yamagami, S. \& Amano, S. Corneal endothelial regeneration and tissue engineering. Prog. Retin. Eye Res. 35, 1-17. https://doi.org/10.1016/j.preteyeres.2013.01.003 (2013).

34. Van den Bogerd, B., Dhubhghaill, S. N., Koppen, C., Tassignon, M. J. \& Zakaria, N. A review of the evidence for in vivo corneal endothelial regeneration. Surv. Ophthalmol. 63, 149-165. https://doi.org/10.1016/j.survophthal.2017.07.004 (2018).

35. Foja, S., Luther, M., Hoffmann, K., Rupprecht, A. \& Gruenauer-Kloevekorn, C. CTG18.1 repeat expansion may reduce TCF4 gene expression in corneal endothelial cells of German patients with Fuchs' dystrophy. Graefes Arch. Clin. Exp. Ophthalmol. 255, 1621-1631. https://doi.org/10.1007/s00417-017-3697-7 (2017).

36. Hessen, M. M., Vahedi, S., Khoo, C. T., Vakili, G. \& Eghrari, A. O. Clinical and genetic investigation of amantadine-associated corneal edema. Clin. Ophthalmol. 12, 1367-1371. https://doi.org/10.2147/OPTH.S166384 (2018).

37. Su, C. C. et al. AICAR induces apoptosis and inhibits migration and invasion in prostate cancer cells through an AMPK/mTORdependent pathway. Int. J. Mol. Sci. https://doi.org/10.3390/ijms20071647 (2019).

38. Lin, K. H. et al. RNA-seq transcriptome analysis of breast cancer cell lines under shikonin treatment. Sci. Rep. 8, 2672. https://doi. org/10.1038/s41598-018-21065-x (2018).

39. Wang, S. C., Chung, J. G., Chen, C. H. \& Chen, S. C. 2- and 4-Aminobiphenyls induce oxidative DNA damage in human hepatoma (Hep G2) cells via different mechanisms. Mutat. Res. 593, 9-21. https://doi.org/10.1016/j.mrfmmm.2005.06.023 (2006).

40. Bischoff, I. et al. Pitfalls in assessing microvascular endothelial barrier function: Impedance-based devices versus the classic macromolecular tracer assay. Sci. Rep. 6, 23671. https://doi.org/10.1038/srep23671 (2016).

\section{Acknowledgements}

This study was supported in part by Grants from the Ministry of Science and Technology, Taiwan, R.O.C. (Grant nos. MOST 108-2320-B-037-007, MOST 108-2314-B-037-079-MY3 and MOST 109-2320-B-037-007-MY3), Kaohsiung Medical University Research Center Grant (KMU-TC108A04), and the Kaohsiung Medical University Chung-Ho Memorial Hospital (Grant no. KMUH105-5M55).

\section{Author contributions}

P.Y.L., S.C.W. and C.Y.L. conceived and designed all the experiments. P.Y.L., Y.H.L., P.L.L., C.C.L., C.C.S., F.Y.C., W.C.C., S.L.H., K.C.C., L.Y.C., T.E.K., C.C.L. and Y.C.C. performed the experiments, data collection and statistical analysis. P.Y.L., S.C.W. and C.Y.L. wrote the manuscript. All authors have read and approved the final version of the manuscript.

\section{Competing interests}

The authors declare no competing interests.

\section{Additional information}

Correspondence and requests for materials should be addressed to S.-C.W. or C.-Y.L.

Reprints and permissions information is available at www.nature.com/reprints.

Publisher's note Springer Nature remains neutral with regard to jurisdictional claims in published maps and institutional affiliations.

(c) (i) Open Access This article is licensed under a Creative Commons Attribution 4.0 International License, which permits use, sharing, adaptation, distribution and reproduction in any medium or format, as long as you give appropriate credit to the original author(s) and the source, provide a link to the Creative Commons licence, and indicate if changes were made. The images or other third party material in this article are included in the article's Creative Commons licence, unless indicated otherwise in a credit line to the material. If material is not included in the article's Creative Commons licence and your intended use is not permitted by statutory regulation or exceeds the permitted use, you will need to obtain permission directly from the copyright holder. To view a copy of this licence, visit http://creativecommons.org/licenses/by/4.0/.

(C) The Author(s) 2021 